\title{
K-Means Kümeleme Algoritması Kullanılarak Olușturulan Yapay Zekâ Modelleri ile Sediment Taşınımının Tespiti
}

\author{
Kemal SAPLIOĞLU1 ${ }^{1}$, Ramazan ACAR ${ }^{2 *}$

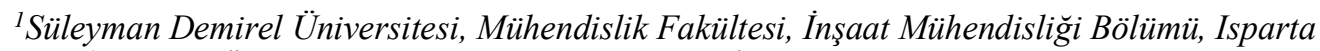 \\ ${ }^{2}$ Munzur Üniversitesi, Mühendislik Fakültesi, İnșaat Mühendisliği Bölümü, Tunceli \\ (ORCID: 0000-0003-0016-8690) (ORCID: 0000-0001-5864-0076)
}

\begin{abstract}
Öz
Akarsulardaki kirlilik seviyelerinin tespiti, kullanma ve içme sularının tedarik edilmesinde, hem baraj hem de bağlama gibi su yapılarının proje aşamasında sediment yükünün doğru bir şekilde tespit edilmesi çok önemlidir. Bu çalışmada, Fırat Havzası üzerinde bulunan üç akım gözlem istasyonu (AGI) için yapay zekâ yöntemlerinden uyarlamalı ağ tabanlı bulanık çıkarım sistemi (ANFIS), yapay sinir ağları (YSA) ve çoklu doğrusal regresyon (MLR) gibi yöntemler denenmiştir. Oluşturulan ANFİS modellerinin küme sayllarının seçiminde ise K-means kümeleme algoritmasından yararlanılmıştır. Yapılan çalışmalarda her bir istasyona ait sediment $\left(\mathrm{Q}_{\mathrm{s}}\right)$, yağış $(\mathrm{P})$, debi $(\mathrm{Q})$ ve sıcaklık $(\mathrm{P})$ verileri kullanılmıştır. Bu veriler kullanılarak her bir istasyon için sediment tahmin modeli geliştirilmiştir. Oluşturulan modelde girdi değiş̧keni olarak yağışın gerçekleştiği günkü değeri (P), yağışın gerçekleştiği günün bir gün öncesindeki değeri $\left(\mathrm{P}_{-1}\right)$, debi ve sıcaklık değerleri, çıktı değişkeni olarak ise sediment konsantrasyonu kullanılmıştır. Oluşturulan bu model tüm istasyonlar için hem eğitim hem de test aşamalarında sırasıyla regresyon katsayısı $\left(\mathrm{R}^{2}\right)$ ve ortalama yüzde hatası $(\mathrm{OYH})$ bakımından karşılaştırılmıştır. Yapılan analizler sonucunda, K-means kümeleme algoritması ile alt küme sayısı belirlenerek oluşturulan ANFIS modelinin hem alt küme sayısı rastgele oluşturulan ANFIS modellerine göre hem de YSA ve MLR modellerine göre daha başarılı sonuçlar elde ettiği görülmüştür. Ayrıca, YSA ve ANFIS yöntemleri modellerinin MLR yöntemi modeline göre gözlenen değerlere daha yakın sonuçlar elde ettiği görülmüştür.
\end{abstract}

Anahtar kelimeler: Sediment, K-means, ANFIS, Yapay Sinir Ağları, Regresyon.

\section{Detection of Sediment Transport with Artificial Intelligence Models Formed by Using K-Means Clustering Algorithm}

\begin{abstract}
It is important to detect sediment load truly in the project process of water structures such as both dam and regulator to determine pollution level, to use and to supply potable water. In this work, methods such as Adaptive Neuro Fuzzy Interference Systems (ANFIS), Artificial Neural Networks (ANN) and Multiple Linear Regression (MLR) are experienced for three Flow Observation Stations on Frrat Basin. K-Means Clustering Algorithm is used to select Clustering numbers of ANFIS Models being formed. Sediment (Qs), Precipitation (P), Flow rate (Q) and temperature $(\mathrm{P})$ data from each station are used in this study. Sediment estimation model is developed for each station by using the data. The value of the day when precipitation occurs $(\mathrm{P})$, the value of the day before precipitation occurs $\left(\mathrm{P}_{-1}\right)$, flow and temperature rates are used as input factors; sediment concentration is used as output factors. The model being formed is compared for all of the stations with regard to regression coefficient $\left(\mathrm{R}^{2}\right)$ and mean percentage error (MPE) in both education and test stages. As a consequence of the analysis, subset numbers of ANFIS model being formed by determining subset of K-Means Clustering Algorithm has more successful results instead of ANFIS Models being randomly formed. It is also observed that the Models of ANFIS and ANN methods have closer results to the values being observed when they are compared to MLR methods.
\end{abstract}

Keywords: Sediment, K-means, ANFIS, Artificial Neural Networks, Regression.

\footnotetext{
"Sorumlu yazar: ramazanacar@munzur.edu.tr

Geliş Tarihi: 26.04.2019, Kabul Tarihi: 02.08.2019
} 


\section{Giriş}

Baraj ve bağlama gibi su yapıları çok çeşitli amaçlar ile (içme suyu, kullanma suyu, enerji üretimi ve taşkın kontrolü) akarsular üzerinde inşa edilmektedir. Su yapılarının havzalarını akarsular beslemektedir. Akarsular beraberinde getirdiği silt, kum, çakıl, kaya parçaları gibi katı maddeler ile baraj göllerini doldururlar. Bundan dolayı barajların depolama kapasitesi ile ekonomik ömürleri azalmaktadır. Bunun sonucunda da baraj ve bağlamaların yıkılması, iş göremez hale gelmesi gibi sorunlar ortaya çıkmaktadır.

Yukarıda belirtilen sorunlardan dolayı sediment taşınımı, akış ve yağış gibi hidrolojik olaylar arasındaki var olan ilişkiyi doğru ve güvenilir bir şekilde belirlemek gerekir. Sediment, yağış ve akış gibi birbirini etkileyen değişkenler arasındaki ilişkinin matematiksel boyutunu belirlemek için YSA [12], ANFIS [3-4] ve MLR [5-6] gibi yöntemler kullanılmaktadır.

Çeribaşı ve Doğan [7] Aşağı Sakarya Nehri için askı maddesi tahmininde yapay sinir ağları (YSA), Mamdani ve Sugeno bulanık mantık (Mamdani-BM, Sugeno-BM) ve adaptif sinirsel bulanık sistemi (ASBS) gibi yöntemleri kullanmışlardır. Oluşturdukları modeller içerisinde ölçüm sonucu elde edilen değerlere en yakın sonucu ASBS yönteminden elde ettiklerini söylemişlerdir.

Kitsikoudis ve diğerleri [8] kum yatağı nehirleri için sediment taşınımı formülleri türetmiş̧lerdir. Bu formülleri türetmek için yapay sinir ağları (YSA), uyarlamalı ağ tabanlı bulanık çıarım sistemi (ANFIS) ve genetik programlama temelli sembolik regresyon yöntemlerini kullanmışlardır. Sonuç olarak, kullandıkları bu yöntemlerin yaygın olarak kullanılan sediment taşınım formüllerine nazaran daha iyi sonuçlar elde ettiğini söylemişlerdir.

Partovian ve diğerleri [9] Minnesota Nehri'nin günlük sediment ve akış modeli üzerinde bir çalışma yapmışlardır. Daha önce ölçülmüş olan verileri kullanarak yapay sinir ağları (YSA) ve uyarlamalı ağ tabanlı bulanık çıkarım sistemi (ANFIS) modellerine uygulamışlardır. Oluşturdukları modellerin performansını değerlendirmek için otomatik regresif entegre hareketli ortalama (ARIMA) ve çoklu doğrusal regresyon (MLR) modelleri ile karşılaştırmışlardır. Sonuç olarak, YSA ve ANFIS modellerinin MLR modeline nazaran daha iyi performans sergilediğini söylemişlerdir.

Firat ve diğerleri [10] Türkiye genelindeki toplam yağış miktarını kümelemek ve homojen bölgeleri belirlemek için K-means algoritmasını kullanmışlardır. Kümeleme analizleri için Türkiye Ulusal Meteoroloji İşleri (DMI) tarafindan işletilen 188 adet istasyondan elde edilen yıllık yağış kayıtları, boylam, enlem ve yükseklik değerlerini kullanmışlardır. Sonuç olarak, yıllık toplam yağışların kümelemesinde K-means algoritması kullanılarak elde edilen sonuçların kabul edilebilir düzeyde olduğunu söylemişlerdir. Kisi ve Zounemat-Kermani [11] askıda sediment konsantrasyonunu tahmin etmek için ANFIS bazlı bulanık C-means kümeleme yaklaşımını (ANFIS-FCM) kullanmışlardır. ANFIS-FCM modellerinin doğruluğu için klasik ANFIS, yapay sinir ağları (YSA) ve sediment anahtar eğrisi yöntemlerini kullanarak karşılaştırma yapmışlardır. Sonuç olarak, ANFIS-FCM modelinin diğer modellere göre daha üstün bir performans sergilediğini söylemişlerdir.

$\mathrm{Bu}$ çalışmada, Fırat Havzası üzerinde bulunan üç akım gözlem istasyonuna ait sediment miktarının tahmin edilmesi, amaçlanmıştır. Bu amaçla istasyonlara ait yağış, sıcaklık ve debi verileri kullanılarak YSA, ANFIS ve MLR modelleri kurulmuştur. Oluşturulan ANFİS modellerinin küme sayılarının seçiminde ise K-means kümeleme algoritmasından yararlanılmıştır. Oluşturulan tüm modeller hem regresyon katsayısı $\left(\mathrm{R}^{2}\right)$ hem de ortalama yüzde hatası $(\mathrm{OYH})$ ile kıyaslanmıştır.

\section{Materyal ve Metot}

\subsection{Materyal}

Çalışma alanı olarak Fırat Havzası seçilmiş̧ir. Fırat Havzası üzerinde birçok akım gözlem istasyonu (AGI) inşa edilmiştir. Bu çalışmada, bu AGI'ler arasından 2102 No'lu Murat Nehri-Palu, 2164 No'lu Göynük Çayı-Çayağzı ve 2166 No'lu Peri Suyu-Loğmar istasyonları kullanılmıştır. Bu AGİ'ler ile ilgili daha detaylı bilgiler aşağıda sıralanmıştır (Şekil 1). 


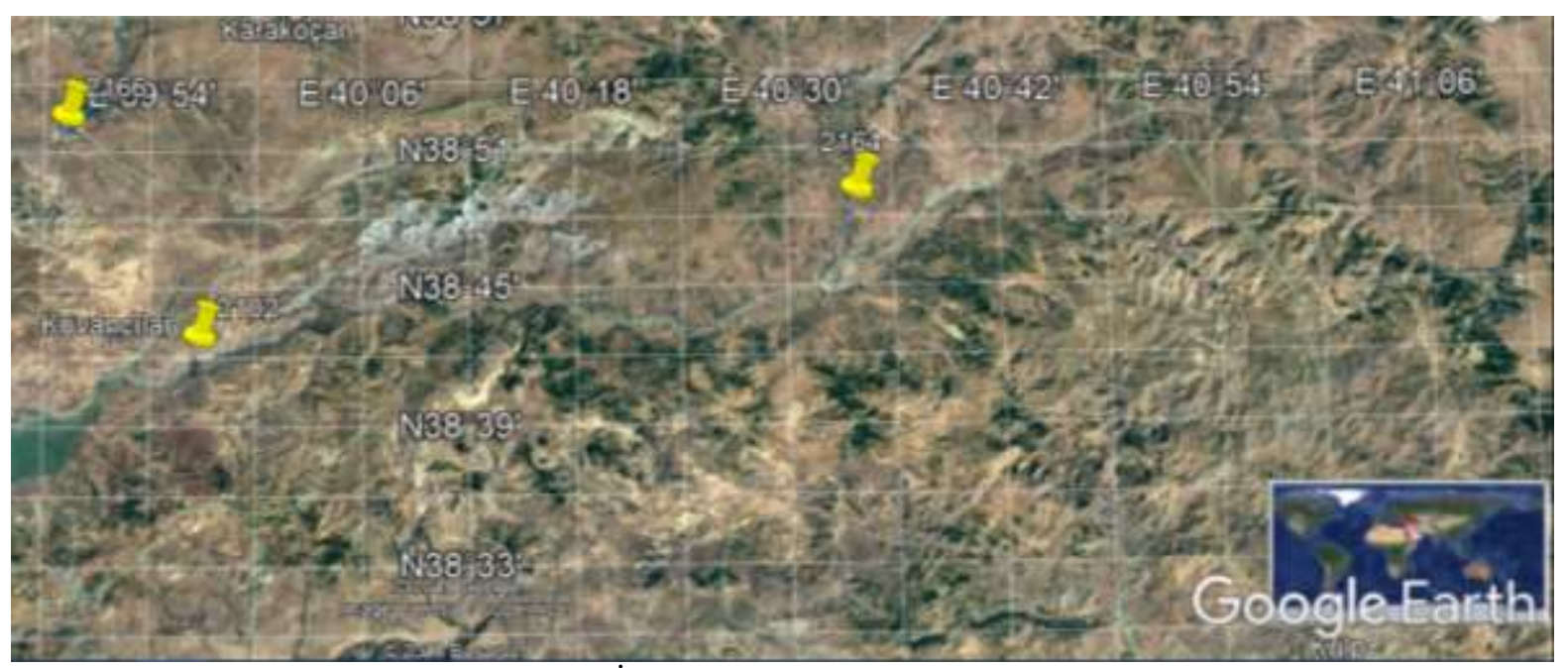

Şekil 1. İstasyonların yerbulundu haritası

2102 No'lu istasyon $38^{\circ} 41^{\prime} 49^{\prime \prime}$ kuzey, 39 56' 22" doğu koordinatlarında ve deniz seviyesinden $859 \mathrm{~m}$ yüksekliktedir. Ayrıca 25515,6 km² alana sahiptir. Tablo 1'de 2102 No'lu istasyon ile ilgili istatistikler verilmiştir.

Tablo 1. 2102 No'lu Murat Nehri-Palu istasyonu

\begin{tabular}{lccccc}
\hline & $\begin{array}{c}\text { Yağış } \\
(\mathbf{m m})\end{array}$ & $\begin{array}{c}\text { Yağış(-1) } \\
(\mathbf{m m})\end{array}$ & $\begin{array}{c}\text { Debi } \\
\left(\mathbf{m}^{\mathbf{3}} / \mathbf{s n}\right)\end{array}$ & $\begin{array}{c}\text { Sıcaklık } \\
\left({ }^{\circ} \mathbf{C}\right)\end{array}$ & $\begin{array}{c}\text { Sediment } \\
\text { Konsantrasyonu } \\
(\mathbf{p p m})\end{array}$ \\
\hline Ortalama & 1.27 & 1.30 & 243.42 & 13.12 & 532.25 \\
\hline Standart Hata & 0.28 & 0.38 & 28.42 & 0.63 & 72.16 \\
\hline Ortanca & 0.00 & 0.00 & 92.21 & 13.00 & 145.80 \\
\hline Standart & 3.49 & 4.70 & 352.67 & 7.85 & 883.83 \\
Sapma & 12.18 & 22.05 & 124372.97 & 61.56 & 781163.22 \\
\hline Örnek Varyans & 23.69 & 59.62 & 9.56 & -1.18 & 13.46 \\
\hline Basıklık & 4.35 & 6.88 & 2.78 & 0.04 & 3.27 \\
\hline Çarpıklık & 27.20 & 46.80 & 2274.96 & 29.00 & 5649.69 \\
\hline Aralık & 0.00 & 0.00 & 14.33 & 0.00 & 20.93 \\
\hline En Küçük & 27.20 & 46.80 & 2289.29 & 29.00 & 5670.62 \\
\hline En Büyük & 195.30 & 199.90 & 37486.92 & 2021.00 & 79837.85 \\
\hline Toplam & 154 & 154 & 154 & 154 & 154 \\
\hline Veri Sayısı & 0.56 & 0.75 & 56.14 & 1.25 & 142.60 \\
\hline Güvenirlik & & & & & \\
\hline Düzeyi(95.0\%) & & & & & \\
\hline
\end{tabular}

2164 No'lu istasyon $38^{\circ} 48^{\prime}$ 06" kuzey, 40 33' 32" doğu koordinatlarında ve deniz seviyesinden 998 m yüksekliktedir. Ayrıca 2232,0 km² alana sahiptir. Tablo 2'de 2164 No'lu istasyon ile ilgili istatistikler verilmiştir. 
Tablo 2. 2164 No'lu Göynük Çayı-Çayağzı istasyonu

\begin{tabular}{lccccc}
\hline & $\begin{array}{c}\text { Yağış } \\
(\mathbf{m m})\end{array}$ & $\begin{array}{c}\text { Yağış(-1) } \\
(\mathbf{m m})\end{array}$ & $\begin{array}{c}\text { Debi } \\
\left(\mathbf{m}^{\mathbf{3}} / \mathbf{s n}\right)\end{array}$ & $\begin{array}{c}\text { Sıcaklık } \\
\left({ }^{\circ} \mathbf{C}\right)\end{array}$ & $\begin{array}{c}\text { Sediment } \\
\text { Konsantrasyonu } \\
(\mathbf{p p m})\end{array}$ \\
\hline Ortalama & 3.12 & 2.35 & 31.01 & 13.04 & 31.02 \\
\hline Standart Hata & 0.71 & 0.52 & 3.79 & 0.60 & 3.59 \\
\hline Ortanca & 0.00 & 0.00 & 10.80 & 12.00 & 6.24 \\
\hline Standart & 8.59 & 6.30 & 45.81 & 7.25 & 43.36 \\
Sapma & 73.72 & 39.64 & 2098.62 & 52.58 & 1880.26 \\
\hline Örnek Varyans & 19.21 & 17.46 & 4.54 & -1.15 & 3.36 \\
\hline Basıklık & 4.06 & 3.79 & 2.21 & 0.21 & 1.83 \\
\hline Çarpıklık & 60.20 & 45.20 & 219.54 & 26.00 & 225.41 \\
\hline Aralık & 0.00 & 0.00 & 1.23 & 1.00 & 0.47 \\
\hline En Küçük & 60.20 & 45.20 & 220.77 & 27.00 & 225.88 \\
\hline En Büyük & 455.20 & 343.50 & 4527.96 & 1904.00 & 4529.41 \\
\hline Toplam & 146 & 146 & 146 & 146 & 146 \\
\hline Veri Sayısı & 1.40 & 1.03 & 7.49 & 1.19 & 7.09 \\
\hline Güvenirlik & & & & & \\
\hline Düzeyi(95.0\%) & & & & & \\
\hline
\end{tabular}

2166 No'lu istasyon $38^{\circ} 51^{\prime} 31^{\prime}$ " kuzey, $39^{\circ} 48^{\prime}$ 50" doğu koordinatlarında ve deniz seviyesinden 847 m yüksekliktedir. Ayrıca 5385,8 km² alana sahiptir. Tablo 3'de 2166 No'lu istasyon ile ilgili istatistikler verilmiştir.

Tablo 3. 2166 No'lu Peri Suyu-Loğmar istasyonu

\begin{tabular}{lccccc}
\hline & $\begin{array}{c}\text { Yağış } \\
(\mathbf{m m})\end{array}$ & $\begin{array}{c}\text { Yağış(-1) } \\
(\mathbf{m m})\end{array}$ & $\begin{array}{c}\text { Debi } \\
\left(\mathbf{m}^{\mathbf{3}} \mathbf{s n}\right)\end{array}$ & $\begin{array}{c}\text { Sıcaklık } \\
\left({ }^{\circ} \mathbf{C}\right)\end{array}$ & $\begin{array}{c}\text { Sediment } \\
\text { Konsantrasyonu } \\
(\mathbf{p p m})\end{array}$ \\
\hline Ortalama & 1.57 & 1.85 & 66.71 & 12.49 & 466.88 \\
\hline Standart Hata & 0.51 & 0.58 & 9.18 & 0.83 & 91.07 \\
\hline Ortanca & 0.00 & 0.00 & 33.76 & 11.50 & 114.41 \\
\hline Standart & 4.40 & 5.04 & 80.05 & 7.20 & 783.45 \\
Sapma & 19.39 & 25.38 & 6408.46 & 51.77 & 613793.95 \\
\hline Örnek Varyans & 11.94 & 13.81 & 4.58 & -1.09 & 5.93 \\
\hline Basıklık & 3.41 & 3.54 & 2.10 & 0.09 & 2.53 \\
\hline Çarpıklık & 23.90 & 29.40 & 391.72 & 24.00 & 3484.90 \\
\hline Aralık & 0.00 & 0.00 & 1.93 & 0.00 & 14.30 \\
\hline En Küçük & 23.90 & 29.40 & 393.64 & 24.00 & 3499.20 \\
\hline En Büyük & 119.40 & 140.60 & 5070.23 & 949.00 & 34549.45 \\
\hline Toplam & 76 & 76 & 76 & 76 & 76 \\
\hline Veri Sayısı & 1.01 & 1.15 & 18.29 & 1.64 & 181.51 \\
\hline Güvenirlik & & & & & \\
\hline Düzeyi(95.0\%) & & & & & \\
\hline
\end{tabular}

Bu çalışmada, 2102 No'lu Murat Nehri-Palu istasyonu ile 2164 No'lu Göynük Çayı-Çayağzı istasyonuna ait 1993-2005 yılları arasında sırasıyla 154'er ve 146'şar adet ölçümler sonucu elde edilmiş 
sıcaklık, sediment ve debi verileri değerlendirilmiştir. 2166 No'lu Peri Suyu-Loğmar istasyonunda ise 1994-2000 yılları arasında 76'şar adet ölçülmüss sıcaklık, sediment ve debi verileri değerlendirilmiştir. Ayrıca her bir istasyonda yağışın gerçekleştiği günkü değerleri ile yağışın gerçekleştiği günün bir gün öncesindeki değerleri girdi verisi olarak değerlendirilmiştir. İstasyonlar için yapılan analizlerde, verilerin eğitim aşaması için ilk \%80 'lik dilimi, test aşaması için ise son \%20'lik dilimi kullanılmıştır.

\subsection{Metot}

Bu bölüm içerisinde yapay sinir ağları (YSA), uyarlamalı ağ tabanlı bulanık çıkarım sistemi (ANFIS), K-means kümeleme yöntemi ve çoklu doğrusal regresyon (MLR) yöntemleri hakkında temel ve teorik bilgiler anlatılmıştır.

\subsubsection{Yapay Sinir Ağları}

YSA, akıllı bir program oluşturmayı amaçlayan bir tekniktir ve bunu da insan beyninde bulunan nöronların çalışma ağlarını simüle eden modelleri kullanarak yapar (Şekil 2). YSA'lar hem keskin bir veriye sahip değillerdir hem de tanıtılan veri kümesine göre çıktılar sağlarlar. Bu yönüyle geleneksel hesaplama programlarından farklıdır. Programa tanımlanan veriler ve koşullar, çeşitli eğitim ve öğrenim metotları yardımıyla işleme alınmaktadır. Bu işlemlerin çıktılarının yardımı sayesinde program veriler ile sinirsel yapılar arasındaki ağırlıkları ayırır. Daha sonra farklı durum ve verilere gelindiği zaman hem durumlar yorumlanır hem de daha önceki ögrenmelere göre sonuçlar sunulur [12].

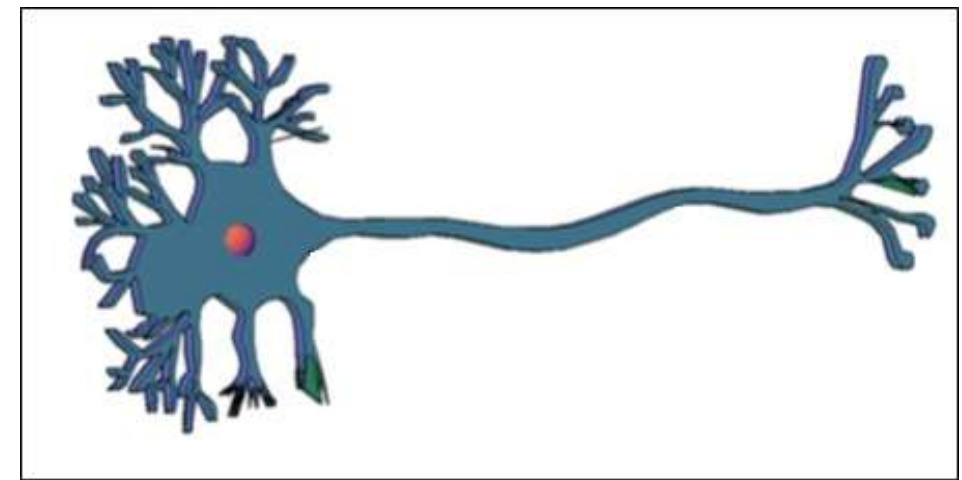

Şekil 2. Biyolojik bir sinir hücresi yapısı [13]

YSA ağı iki bölümde incelenebilir. Bu bölümlerden biri YSA'nın yapısı diğeri ise bu yapının işlemesinde etkin rol oynayan matematiksel fonksiyonlardır. YSA yapısı girdi, gizli ve çıktı olmak üzere üç katmandan oluşur (Şekil 3)[12].

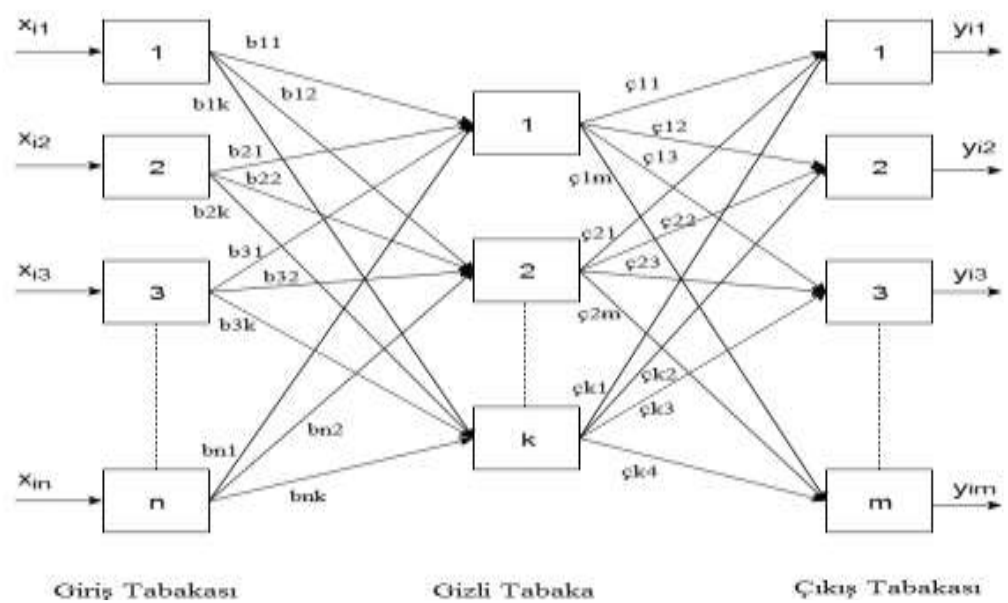

Şekil 3. Genel yapay sinir ağ mimarisi 
Girdi katmanı: YSA bu katmanda normal sistemler gibi davranır ve giriş verileri doğrultusunda sonuçlar üretir. Bu giriş verileri hem dış dünyadan ve hem de diğer YSA hücrelerinden gelebilir. Burada bulunan nöron sayısı ile dışardan gelen giriş sayısı eşittir. Girdi katmanında genelde verilerin işlemlere tabi tutulmadığı belirtilmiştir [14].

Gizli tabaka: Bu tabakadaki nöron sayısı hem girdi hem de çıktı sayısından bağımsızdır. Hem ara katmanlarda ve hem de gizli tabakadaki nöron sayısının artması durumunda hesap karmaşıklığı ve hesap süresi artar. Buna rağmen yapay sinir ağlarının çok daha karmaşık sorunların çözümü için kullanılabilmesinde etkin rol oynadığı belirtilmiştir [14].

Çıktı katmanı: Ara katmandan iletilen bilgiler son olarak burada işlenir. Daha sonra girdi katmanında bulunan girdilere karşıllk olarak ağ tarafindan üretilen çıkışlar belirlenir ve kullanıma hazır bilgi haline getirildiği belirtilmiştir [14].

\subsubsection{Uyarlamalı Ağ Tabanlı Bulanık Çıkarım Sistemi}

Uyarlamalı ağlar çerçevesinde uygulanan bir bulanık çıkarım sistemi olan ANFIS ilk olarak Jang (1993) tarafından geliştirilmiş olan bir modeldir. ANFIS' in amacı kuralları otomatik olarak elde etmektir ve bu yönüyle de bulanık mantıktan farklıdır. ANFIS yapısı bulanık mantık çıkarımı ile birlikte yapay sinir ağlarının öğrenme yeteneğini de kullanır. Bu yönüyle ANFIS hem bulanık mantığın ve hem de YSA modelinin tek başına çalıştırılmasından daha başarılıdır. Girdi değerleri ile çıktı değerleri bilindiği zaman, ANFIS olası tüm kuralları belirler (Denklem 1). ANFIS modeli beş tabakadan oluşur. Bu tabakalar sırasıyla buzlanma, kural, normalleşme, bulanıklaştırma ve toplama tabakalarıdır (Şekil 3) [15].

$$
\begin{array}{ll}
f_{1}=p_{1} a+q_{1} b+r_{1} & f=\frac{w_{1} f_{1}+w_{2} f_{2}}{w_{1}+w_{2}} \\
f_{2}=p_{2} a+q_{2} b+r_{2} & f=\bar{w}_{1} f_{1}+\bar{w}_{2} f_{2}
\end{array}
$$

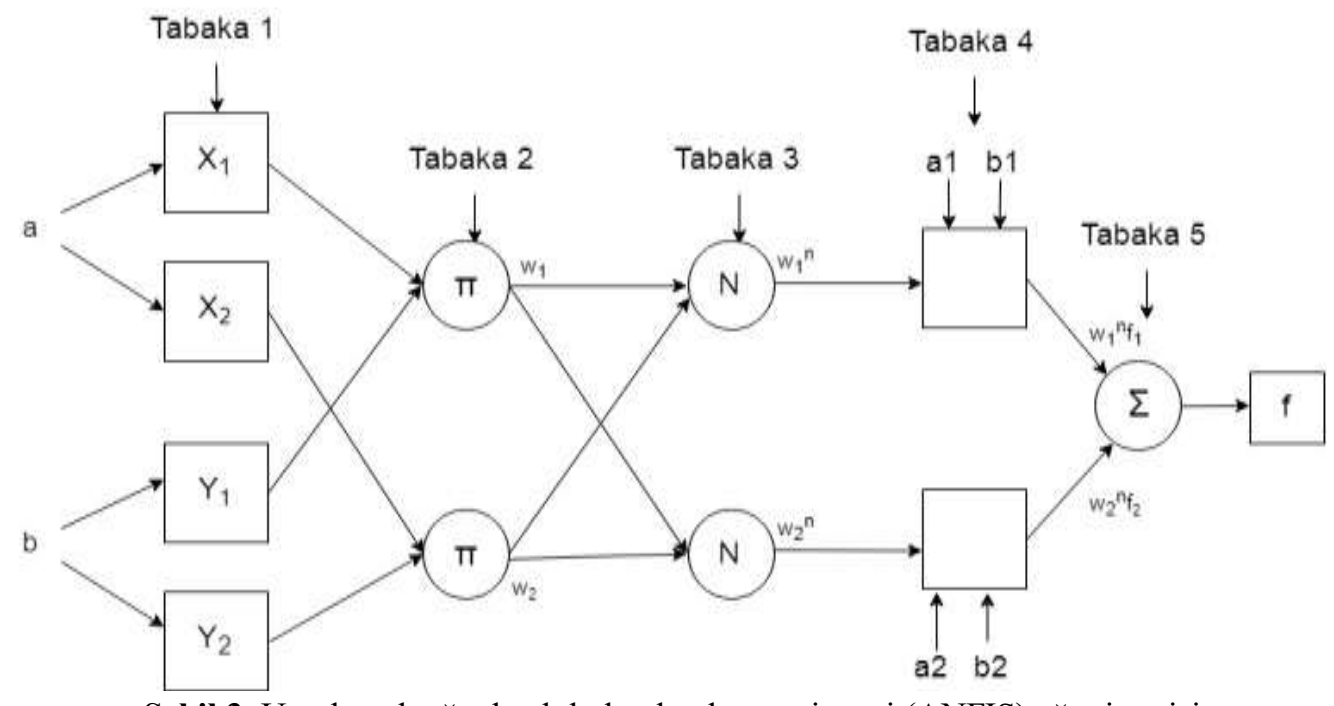

Şekil 3. Uyarlamalı ăg tabanlı bulanık çıkarım sistemi (ANFIS) ă̆ mimarisi

1. Tabaka: $X$ ve $Y$ iki özgün girdi değerleridir. $X$ ve $Y$ iki giriş dügümünde beslenirler ve bu da değerleri üyelik işlevlerine dönüştürür.

$$
\begin{array}{ll}
O_{i}{ }^{1}=\mu_{A \dot{I}}(a) & \mathrm{i}=1,2 \\
O_{i}{ }^{1}=\mu_{B \dot{I}-2}(b) & \mathrm{i}=3,4
\end{array}
$$


Burada, $\mathrm{O}_{1}^{\mathrm{j}} \mathrm{j}$ katmanında $\mathrm{i}$ çıkış düğümünü, a veya $\mathrm{b}$ girdi değerini, $\mu_{\mathrm{Ai}}$ veya $\mu_{\mathrm{Bi}-2}$ ise bu tabaka ile ilişkili bulanık kümesinin ifade edildiği belirtilmiştir [16].

2. Tabaka: Bu katmanda yer alan her düğüm aldığı sinyalleri çoğaltır. Düğümün $\mathrm{O}_{\mathrm{i}}^{2}$ çıktıs1 Denklem (4)'deki gibi hesaplanabildiği belirtilmiştir [16]:

$$
O_{i}^{2}=W_{i}=\mu_{A i}(a) \cdot \mu_{B i}(b) \quad \mathrm{i}=1,2
$$

3. Tabaka: Bu tabakadaki düğümlerin çıkışı Denklem (5)'dekine benzer ilişki kullanılarak elde edildiği belirtilmiştir [16]:

$$
O_{i}^{3}=\bar{w}_{i}=\frac{w_{1}}{w_{1}+w_{2}} \quad \quad \mathrm{i}=1,2
$$

4. Tabaka: Bu tabakada 'i' düğümü birinci kural yöntemine bağlı olarak tanımlanan çıktı modelinin işlevinde 'i' sıralı kuralının sağladığı katkının hesaplandığı belirtilmiştir [16]:

$$
O_{i}^{4}=\bar{w}_{i} f_{i}=\bar{w}_{i}\left(p_{i} A+q_{i} B+r_{i}\right) \quad \mathrm{i}=1,2
$$

Burada, $\bar{w}_{i}$ üçüncü tabakanın çıktısını, $p_{i}, q_{i}$ ve $r_{i}$ ise parametre kümelerini ifade eder.

5. Tabaka: Bu tabakanın tek dügümü, sistemin ağırlıklı küresel (global) çıktısını Denklem (7)'deki gibi hesaplandığı belirtilmiştir [16]:

$$
O_{i}^{5}=\bar{w}_{i} f_{i}=\frac{\sum_{i} w_{i} f_{i}}{\sum_{i} w_{i}}
$$

$f$ 'in sabit olduğu durumlarda, sıfır sıralı bir Sugeno [8] bulanık modeli elde edilir. Bu da hem Mamdani bulanık çıkarım sisteminin [17] ve hem de Tsukamoto bulanık modelinin [18] özel bir durumu olarak görülebilir. Buna ek olarak, sıfır sıralı bir Sugeno bulanık modeli, bazı küçük kısıtlamalar altında radyal temel fonksiyon ağına işlevsel olarak eşdeğerdir [19].

\subsubsection{K-means Algoritması ile Kümeleme}

Bulanık K-means yöntemi ilk olarak 1967 yılında J. MacQueen tarafindan kullanılan denetimsiz bir modelleme algoritmasıdır. Bu yöntem orta noktaya ya da en yakın merkeze göre var olan kategorileri veya koşulları baz alarak birkaç nesneyi bölümlere ayırarak çalışır. Bu yöntem aynı küme içerisinde bulunan veriler arasındaki değişimi en aza indirir. Aynı zamanda farklı kümeler içerisindeki veriler arasındaki değişimi de en üst seviyeye çıkarır [20-21]. Bu yöntem jeohidroloji, toprak bilimi ve bitki örtüsü haritalandırma alanlarında kullanılan bir tekniktir [22-24]. K-Means kümeleme algoritması aşağıdaki adımlardan oluşmaktadır [25-26]:

- Veri noktaları $X_{i}$ ve küme sayıları $K$ olarak belirlenir. ( $(\mathrm{i}=1,2, \ldots, \mathrm{n})$

- Daha sonra veri noktaları rastgele kümelere ayrılır. Sonra tüm $C_{j}$ küme merkezleri $j=1,2, \ldots, k$ şeklinde hesaplanir.

- Her küme içerisinde her bir veri noktasının merkezlere olan uzaklığı hesaplanır. Bu yapılırken seçilen mesafe algoritması kullanılır. Sadece girdi parametresine göre yapıldığında X mesafesi kullanılırken hem girdi hem de çıktı verilerinin birlikte kullanıldığı uzayda mesafe bulma işleminde Öklit mesafesi kullanilabilir. 
- Mesafelere bakılarak hangi verinin hangi kümeye ait olduğu tespit edilir.

- Oluşturulan her bir kümenin ağırlık merkezleri tekrardan hesaplanır. Yeni oluşacak ağırlık merkezlerine göre mesafe bulma işlemleri tekrarlanır.

- Kümeler arası geçiş olmadığı ya da başka bir deyiş̧le ağırlık merkezlerinin değişmediği anda işlemler sonlandirilir.

\subsection{4. Çoklu Doğrusal Regresyon}

Çoklu regresyon analizi, birbirini etkileyen değişkenler arasındaki ilişkinin matematiksel boyutunu belirlemek için kullanılan istatistiksel bir metottur. Çoklu regresyon analizine bağlı olarak formüle edilen denklem kullanılarak tahmin edilecek değer onu etkileyen tüm değerlerin bir fonksiyonu şeklinde yazılır (Denklem 8) [27-28].

$$
\mathrm{Y}=\mathrm{a}_{1} \mathrm{X}_{1}+\mathrm{a}_{2} \mathrm{X}_{2}+\ldots+\mathrm{a}_{\mathrm{m}} \mathrm{X}_{\mathrm{m}}+\mathrm{u}
$$

Burada;

Y: Bağımlı değişkeni,

$\mathrm{x}$ : Bağımsız değişkeni,

a: Regresyon katsayısinı,

m: Giriş parametrelerinin sayısını,

u: Hata terimini ifade eder.

Veriler normal olarak dağıtıldığı zaman çoklu doğrusal regresyon analizi kullanılabilir. Bağımlı ve bağımsız değişkenler arasındaki ilişki doğrusaldır. Ayrıca her bağımsız değişken için hata varyansı sabittir [27-29].

\section{Bulgular ve Tartışma}

\subsection{Analizler için Oluşturulan Modeller}

2102 No'lu Murat Nehri-Palu, 2164 No'lu Göynük Çayı-Çayağzı ve 2166 No'lu Peri Suyu-Loğmar istasyonları için yağı̧ı̧ı gerçekleştiği günkü değeri (P), yağışın gerçekleştiği günün bir gün öncesindeki değeri $\left(\mathrm{P}_{-1}\right)$, debi $(\mathrm{Q})$ ve sıcaklık $(\mathrm{T})$ verileri girdi olarak, sediment konsantrasyonu $(\mathrm{C})$ verisinin de çıktı olarak kullanıldığı yapay sinir ağları (YSA), çoklu doğrusal regresyon (MLR) ve uyarlamalı ağ tabanlı bulanık çıkarım sistemi (ANFIS) modelleri oluşturulmuştur. ANFIS yönteminde oluşturulan küme sayıları K-means algoritması ile belirlenmiştir. Yapay sinir ağları kullanılarak üç istasyon için de 10'ar adet model oluşturulmuştur. ANFIS kullanılarak üç istasyon için de 6'şar adet model oluşturulmuştur.

\subsection{No'lu İstasyon için Tahmin Sonuçları}

Çalışmada öncelikle gözlem istasyonlarında yapılan ölçümler sonucu elde edilen veriler K-means algoritması kullanılarak kümelenmiştir. Farklı iki kümeleme işlemi yapılımıştır:

1. Veriler birbirleriyle kendi içerisinde kümelenmiştir.

2. Girdi verilerine karşılık gelen çıktı verilerinin konumları kümelenmiştir.

K-means algoritması ile kümelemeye ait sonuçlar Tablo 4'te sunulmuştur. 
Tablo 4. K-means algoritması ile yapılan kümelemeye ait bilgiler

\begin{tabular}{|c|c|c|c|c|c|c|c|c|c|c|c|c|c|}
\hline & \multirow{2}{*}{$\begin{array}{l}\text { Küme } \\
\text { Sayısı }\end{array}$} & \multicolumn{2}{|c|}{ Küme 1} & \multicolumn{2}{|c|}{ Küme 2} & \multicolumn{2}{|c|}{ Küme 3} & \multicolumn{2}{|c|}{ Küme 4} & \multicolumn{2}{|c|}{ Küme 5} & \multicolumn{2}{|c|}{ Küme 6} \\
\hline & & $\begin{array}{l}\text { E. } \\
\text { S. }\end{array}$ & Ort. & $\begin{array}{l}\text { E. } \\
\text { S. }\end{array}$ & Ort. & $\begin{array}{l}\text { E. } \\
\text { S. }\end{array}$ & Ort. & $\begin{array}{l}\text { E. } \\
\text { S. }\end{array}$ & Ort. & $\begin{array}{l}\text { E. } \\
\text { S. }\end{array}$ & Ort. & $\begin{array}{l}\text { E. } \\
\text { S. }\end{array}$ & Ort \\
\hline \multirow{5}{*}{ 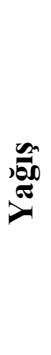 } & 2 & 137 & 0.57 & 6 & 13.9 & - & - & - & - & - & - & - & - \\
\hline & 3 & 127 & 0.21 & 15 & 7.23 & 1 & 27.2 & - & - & - & - & - & - \\
\hline & 4 & 123 & 0.12 & 14 & 4.54 & 5 & 11.34 & 1 & 27.2 & - & - & - & - \\
\hline & 5 & 115 & 0.02 & 12 & 2.01 & 12 & 5.80 & 3 & 12.9 & 1 & 27.2 & - & - \\
\hline & 6 & 115 & 0.02 & 12 & 2.01 & 10 & 5.18 & 2 & 8.90 & 3 & 12.9 & 1 & 27.2 \\
\hline \multirow{5}{*}{ อ̃ } & 2 & 125 & 125.9 & 18 & 1050 & - & - & - & - & - & - & - & - \\
\hline & 3 & 119 & 105.2 & 21 & 790 & 3 & 1837 & - & - & - & - & - & - \\
\hline & 4 & 110 & 87.07 & 16 & 426 & 14 & 909 & 3 & 1837 & - & - & - & - \\
\hline & 5 & 110 & 87.02 & 15 & 411 & 14 & 867 & 3 & 1488 & 1 & 2289 & - & - \\
\hline & 6 & 75 & 54.35 & 32 & 149 & 12 & 304 & 12 & 634 & 9 & 1000 & 3 & 1837 \\
\hline \multirow{5}{*}{ 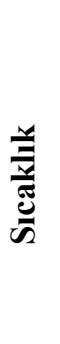 } & 2 & 73 & 7.18 & 70 & 20.4 & - & - & - & - & - & - & - & - \\
\hline & 3 & 44 & 4.41 & 39 & 12.1 & 60 & 21.4 & - & - & - & - & - & - \\
\hline & 4 & 44 & 4.41 & 38 & 12.0 & 30 & 18.5 & 31 & 24.1 & - & - & - & - \\
\hline & 5 & 28 & 2.89 & 22 & 7.68 & 32 & 12.56 & 30 & 18.56 & 31 & 24.10 & - & - \\
\hline & 6 & 15 & 1.73 & 29 & 5.79 & 38 & 12.0 & 28 & 18.3 & 22 & 22.8 & 11 & 26 \\
\hline
\end{tabular}

Bu tabloda; E. S. kısaltması eleman sayısını, Ort. kısaltması ise ortalama anlamlarını ifade etmektedir. Elde edilen sonuçlara bakıldığında; homojen dağılım gösteren elemanların yağış için iki küme, debi için altı küme ve sıcaklık için dört küme olduğu görülmektedir. Tablo 5 'in yöntem bölümünde bu kümeler işaretlenmiştir. Çalışmada K-means yöntemi ile oluşturulan ANFIS yöntemi modellerinin yanı sıra rastgele oluşturulan farklı alt kümelerle yapılan ANFIS modelleri de oluşturulmuştur. YSA ve ANFIS sediment modellerinin güvenilirliğinin kontrolünde daha hassas bir karşılaştırma yapabilmek için MLR modeli oluşturularak karşılaştırma yapılmıştır. Tablo 5'te küme sayısı belirlenen girdi değerleri ile oluşturulan ANFIS modelleri, YSA ve MLR modellerine ait sonuçlar verilmiştir. Tablo 5 incelendiğinde, K-means algoritması ile belirlenen en uygun alt küme sayıları ile oluşturulan ANFIS modelinden, hem rastgele oluşturulan ANFIS modellerine göre hem de YSA ve MLR modellerine göre daha iyi sonuçlar elde edildiği görülmüştür. Şekil 5'te en iyi sonuçların elde edildiği modele ait eğitim ve test aşamalarının $\mathrm{R}^{2}$ grafikleri verilmiştir. Ayrıca Denklem 9'da geliştirilen MLR modelinden elde edilen en iyi $\mathrm{R}^{2}$ değerinin denklemi verilmiştir. En başarılı model; test aşamasına ait en büyük $R^{2}$ ye göre belirlemiştir. Bu istasyonda en başarılı sonuç $\mathbf{R}^{2}=\mathbf{0 . 9 8 6 6}$ değeri ile alt küme sayısı K-means algoritması ile belirlenen ANFIS modelinden elde edilmiştir (Şekil 6).

$$
X_{2102}=X_{p} * 80.862+X_{p_{(-1)}} * 11.376+X_{Q} * 1.846+X_{T} *(-0.725)+52.413
$$


Tablo 5. Oluşturulan YSA, ANFIS ve MLR modellerine ait $\mathrm{R}^{2}$ ve hata değerleri

\begin{tabular}{ccccccc}
\hline \multirow{2}{*}{ Yöntem } & \multicolumn{2}{c}{ Ĕ̈̆tim } & \multicolumn{5}{c}{ Test } \\
\cline { 2 - 7 } & $\mathrm{R}^{2}$ & MSE & MAPE & $\mathrm{R}^{2}$ & MSE & MAPE \\
\hline YSA - 1 Nöron & 0.7192 & 5.754 & 5.236 & 0.7012 & 5.422 & 5.263 \\
\hline YSA - 2 Nöron & 0.8017 & 5.448 & 5.302 & 0.7861 & 4.656 & 4.534 \\
\hline YSA - 3 Nöron & 0.8200 & 4.437 & 4.125 & 0.7465 & 4.060 & 3.716 \\
\hline YSA - 4 Nöron & 0.8552 & 4.191 & 3.983 & 0.8300 & 4.125 & 3.856 \\
\hline YSA - 5 Nöron & 0.8860 & 4.275 & 4.107 & 0.8414 & 3.929 & 3.516 \\
\hline YSA - 6 Nöron & 0.8226 & 3.959 & 3.741 & 0.7114 & 3.427 & 3.157 \\
\hline YSA - 7 Nöron & 0.8929 & 3.574 & 3.356 & 0.7739 & 4.603 & 4.208 \\
\hline YSA - 8 Nöron & 0.9092 & 4.661 & 4.215 & 0.8401 & 4.548 & 4.196 \\
\hline YSA - 9 Nöron & 0.8840 & 5.025 & 4.842 & 0.8780 & 4.764 & 4.532 \\
\hline YSA - 10 Nöron & 0.9436 & 4.513 & 4.208 & 0.8840 & 4.202 & 4.152 \\
\hline ANFIS - 2-2-6-4 Alt Küme & $\mathbf{0 . 9 8 5 3}$ & $\mathbf{1 . 7 6 3}$ & $\mathbf{1 . 6 9 1}$ & $\mathbf{0 . 9 8 6 6}$ & $\mathbf{1 . 9 4 7}$ & $\mathbf{1 . 8 5 7}$ \\
\hline ANFIS - 3-3-3-3 Alt Küme & 0.8962 & 3.389 & 3.109 & 0.8021 & 4.819 & 4.759 \\
\hline ANFIS - 4-4-4-4 Alt Küme & 0.9236 & 3.857 & 3.641 & 0.8207 & 4.958 & 4.841 \\
\hline ANFIS - 5-5-5-5 Alt Küme & 0.9536 & 3.017 & 2.856 & 0.9514 & 4.999 & 4.602 \\
\hline ANFIS - 6-6-6-6 Alt Küme & 0.9661 & 2.466 & 2.178 & 0.9381 & 5.901 & 5.841 \\
\hline ANFIS - 7-7-7-7 Alt Küme & 0.9773 & 1.960 & 1.759 & 0.9736 & 5.123 & 4.786 \\
\hline MLR & 0.8586 & 4.154 & 3.891 & 0.8368 & 4.542 & 4.149 \\
\hline & & & & & & \\
\hline & & & & \\
\hline
\end{tabular}

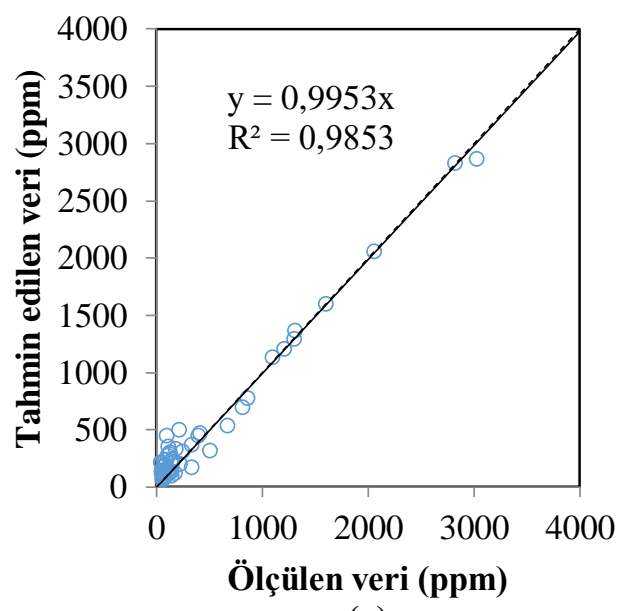

(a)

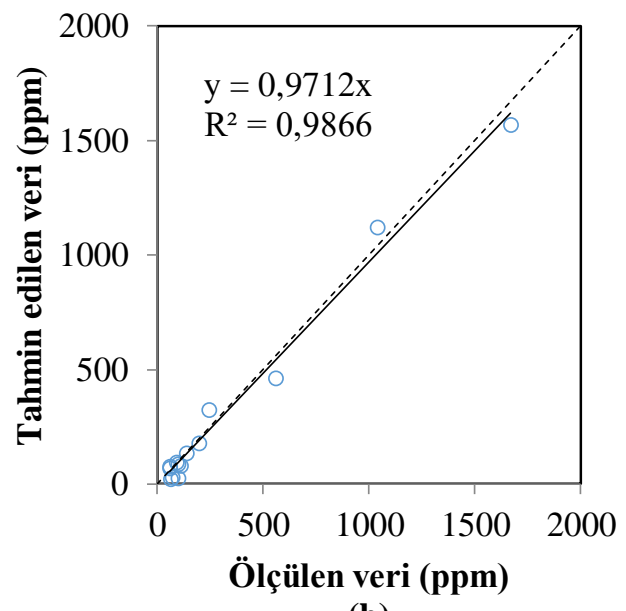

(b)

Şekil 5. Dört girdili ve 2-2-6-4 alt kümeli ANFIS modeline ait saçılım diyagramları (a) eğitim; (b) test 


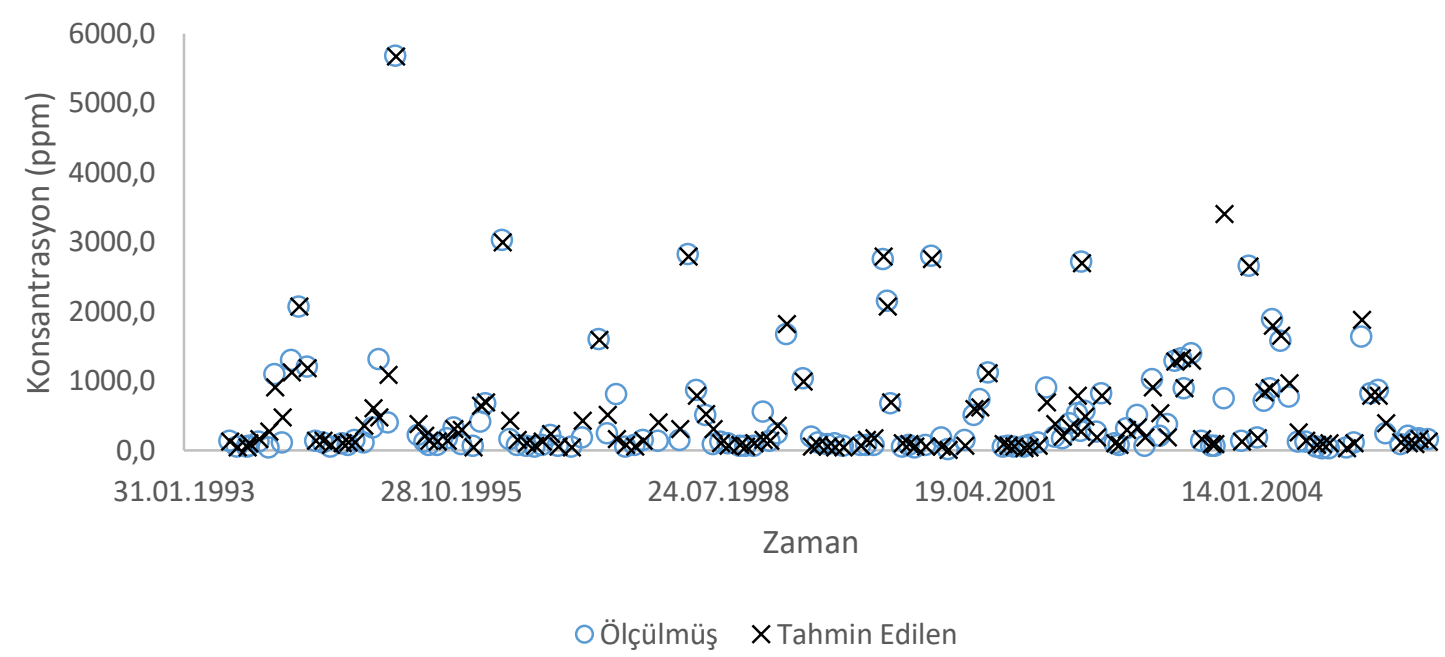

Şekil 6. Dört girdili ve 2-2-6-4 alt kümeli ANFIS modeline ait zaman serisi grafiği

\subsection{No'lu İstasyon için Tahmin Sonuçları}

Çalışmada öncelikle gözlem istasyonlarında yapılan ölçümler sonucu elde edilen veriler K-means algoritması kullanılarak kümelenmiştir. Farklı iki kümeleme işlemi yapılmıştır:

1. Veriler birbirleriyle kendi içerisinde kümelenmiştir.

2. Girdi verilerine karşılık gelen çıktı verilerinin konumları kümelenmiştir.

K-means algoritması ile kümelemeye ait sonuçlar Tablo 6'da sunulmuştur.

Tablo 6. K-means algoritması ile yapılan kümelemeye ait bilgiler

\begin{tabular}{|c|c|c|c|c|c|c|c|c|c|c|c|c|c|}
\hline & \multirow{2}{*}{$\begin{array}{l}\text { Küme } \\
\text { Sayısı }\end{array}$} & \multicolumn{2}{|c|}{ Küme 1} & \multicolumn{2}{|c|}{ Küme 2} & \multicolumn{2}{|c|}{ Küme 3} & \multicolumn{2}{|c|}{ Küme 4} & \multicolumn{2}{|c|}{ Küme 5} & \multicolumn{2}{|c|}{ Küme 6} \\
\hline & & $\begin{array}{l}\text { E. } \\
\text { S. }\end{array}$ & Ort. & $\begin{array}{l}\text { E. } \\
\text { S. }\end{array}$ & Ort. & $\begin{array}{l}\text { E. } \\
\text { S. }\end{array}$ & Ort. & $\begin{array}{l}\text { E. } \\
\text { S. }\end{array}$ & Ort. & $\begin{array}{l}\text { E. } \\
\text { S. }\end{array}$ & Ort. & $\begin{array}{l}\text { E. } \\
\text { S. }\end{array}$ & Ort \\
\hline \multirow{5}{*}{ 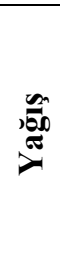 } & 2 & 125 & 1.08 & 8 & 33.21 & & & & & & & & \\
\hline & 3 & 118 & 0.45 & 11 & 15.35 & 4 & 44.70 & & & & & & \\
\hline & 4 & 113 & 0.22 & 12 & 9.23 & 5 & 24.20 & 3 & 48.23 & & & & \\
\hline & 5 & 111 & 0.14 & 12 & 7.49 & 6 & 19.43 & 3 & 39.53 & 1 & 60.2 & & \\
\hline & 6 & 111 & 0.14 & 8 & 5.74 & 6 & 12.28 & 4 & 21.72 & 3 & 39.53 & 1 & 60.2 \\
\hline \multirow{5}{*}{$\ddot{\overline{0}}$} & 2 & 113 & 11.79 & 20 & 116.8 & & & & & & & & \\
\hline & 3 & 109 & 10.17 & 12 & 69.71 & 12 & 143.5 & & & & & & \\
\hline & 4 & 87 & 6.42 & 23 & 25.83 & 11 & 72.10 & 12 & 143.5 & & & & \\
\hline & 5 & 87 & 6.42 & 23 & 25.82 & 11 & 72.10 & 10 & 131.5 & 2 & 203.6 & & \\
\hline & 6 & 87 & 6.42 & 23 & 25.82 & 10 & 69.56 & 6 & 116.4 & 5 & 142.9 & 2 & 203.6 \\
\hline \multirow{5}{*}{ 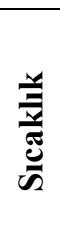 } & 2 & 74 & 7.54 & 59 & 20.28 & & & & & & & & \\
\hline & 3 & 35 & 4.34 & 45 & 10.91 & 53 & 20.98 & & & & & & \\
\hline & 4 & 35 & 4.34 & 39 & 10.41 & 32 & 17.47 & 27 & 23.63 & & & & \\
\hline & 5 & 31 & 4 & 25 & 8.64 & 24 & 12.63 & 26 & 18.23 & 27 & 23.63 & & \\
\hline & 6 & 18 & 3.06 & 17 & 5.71 & 23 & 9.35 & 25 & 13.76 & 30 & 19.87 & 17 & 24.71 \\
\hline
\end{tabular}

$\mathrm{Bu}$ tabloda; E. S. kısaltması eleman sayısını, Ort. kısaltması ise ortalama anlamlarını ifade etmektedir. Elde edilen sonuçlara bakıldığında; homojen dağılım gösteren elemanların yağış için üç küme, debi için beş küme ve sıcaklık için dört küme olduğu görülmektedir. Tablo 7'nin yöntem bölümünde bu kümeler işaretlenmiştir. Çalışmada K-means yöntemi ile oluşturulan ANFIS yöntemi modellerinin yanı sıra rastgele oluşturulan farklı alt kümelerle yapılan ANFIS modelleri de oluşturulmuştur. YSA ve ANFIS sediment modellerinin güvenilirliğinin kontrolünde daha hassas bir karşılaştırma yapabilmek için MLR modeli oluşturularak karşılaştırma yapılmıştır. Tablo 7 'de küme 
sayısı belirlenen girdi değerleri ile oluşturulan ANFIS modelleri, YSA ve MLR modellerine ait sonuçlar verilmiştir. Tablo 7 incelendiğinde, K-means algoritması ile belirlenen en uygun alt küme sayıları ile oluşturulan ANFIS modelinden, hem rastgele oluşturulan ANFIS modellerine göre hem de YSA ve MLR modellerine göre daha iyi sonuçlar elde edildiği görülmüştür. Şekil 7'de en iyi sonuçların elde edildiği modele ait eğitim ve test aşamalarının $\mathrm{R}^{2}$ grafikleri verilmiştir. Ayrıca Denklem 10'da geliştirilen MLR modelinden elde edilen en iyi $\mathrm{R}^{2}$ değerinin denklemi verilmiştir. En başarılı model; test aşamasına ait en büyük $R^{2}$ ye göre belirlemiştir. Bu istasyonda en başarılı sonuç $\mathbf{R}^{2}=\mathbf{0 . 9 9 6 4}$ değeri ile alt küme sayısı K-means algoritması ile belirlenen ANFIS modelinden elde edilmiştir (Şekil 8).

$$
X_{2164}=X_{p} *(-0.02)+X_{p_{(-1)}} *(-0.59)+X_{Q} *(-0.23)+X_{T} * 3.97+(-12.186)
$$

Tablo 7. Oluşturulan YSA, ANFIS ve MLR modellerine ait $\mathrm{R}^{2}$ ve hata değerleri

\begin{tabular}{ccccccc}
\hline \multirow{2}{*}{ Yöntem } & \multicolumn{2}{c}{ Eğitim } & \multicolumn{3}{c}{ Test } \\
\cline { 2 - 7 } & $\mathrm{R}^{2}$ & MSE & MAPE & $\mathrm{R}^{2}$ & MSE & MAPE \\
\hline YSA - 1 Nöron & 0.9419 & 4.120 & 3.956 & 0.9302 & 3.660 & 3.508 \\
\hline YSA - 2 Nöron & 0.9944 & 3.040 & 2.949 & 0.9930 & 2.725 & 2.685 \\
\hline YSA - 3 Nöron & 0.8716 & 6.088 & 5.769 & 0.8676 & 5.332 & 5.186 \\
\hline YSA - 4 Nöron & 0.9724 & 3.387 & 3.152 & 0.9646 & 3.336 & 3.242 \\
\hline YSA - 5 Nöron & 0.9961 & 1.169 & 1.126 & 0.9949 & 1.224 & 1.154 \\
\hline YSA - 6 Nöron & 0.9513 & 2.644 & 2.463 & 0.9236 & 2.516 & 2.365 \\
\hline YSA - 7 Nöron & 0.9968 & 1.532 & 1.478 & 0.9922 & 1.491 & 1.395 \\
\hline YSA - 8 Nöron & 0.9979 & 1.022 & 1.015 & 0.9911 & 1.192 & 1.099 \\
\hline YSA - 9 Nöron & 0.9976 & 1.158 & 1.134 & 0.9928 & 1.048 & 1.021 \\
\hline YSA - 10 Nöron & 0.9719 & 2.970 & 2.763 & 0.9641 & 2.518 & 2.356 \\
\hline ANFIS - 3-3-3-3 Alt Küme & 0.8995 & 3.174 & 3.085 & 0.8785 & 4.323 & 4.128 \\
\hline ANFIS -3-3-5-4 Alt Küme & $\mathbf{0 . 9 9 6 7}$ & $\mathbf{1 . 0 0 3}$ & $\mathbf{0 . 9 8 6}$ & $\mathbf{0 . 9 9 6 4}$ & $\mathbf{1 . 0 1 9}$ & $\mathbf{0 . 9 9 3}$ \\
\hline ANFIS - 4-4-4-4 Alt Küme & 0.8928 & 2.472 & 2.152 & 0.8908 & 4.434 & 4.215 \\
\hline ANFIS - 5-5-5-5 Alt Küme & 0.9279 & 1.510 & 1.486 & 0.9122 & 3.760 & 3.609 \\
\hline ANFIS - 6-6-6-6 Alt Küme & 0.9176 & 1.221 & 1.111 & 0.8871 & 3.082 & 2.863 \\
\hline ANFIS - 7-7-7-7 Alt Küme & 0.9129 & 1.023 & 1.018 & 0.8706 & 2.462 & 2.309 \\
\hline MLR & 0.7284 & 5.151 & 4.963 & 0.6357 & 5.110 & 4.825 \\
\hline
\end{tabular}

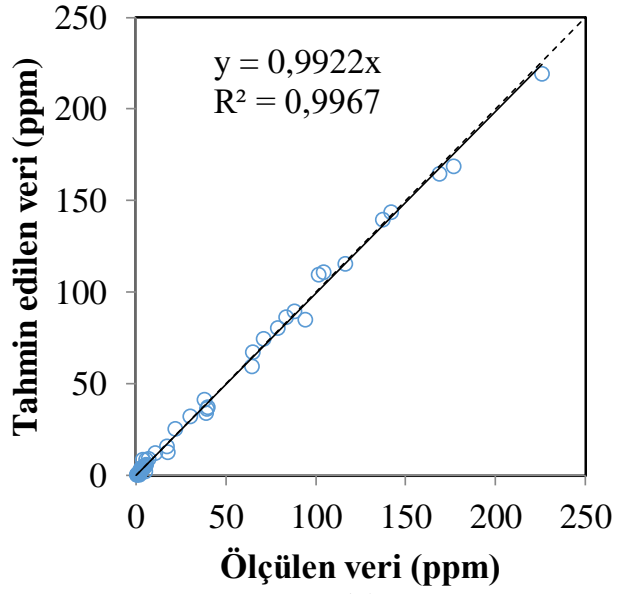

(a)

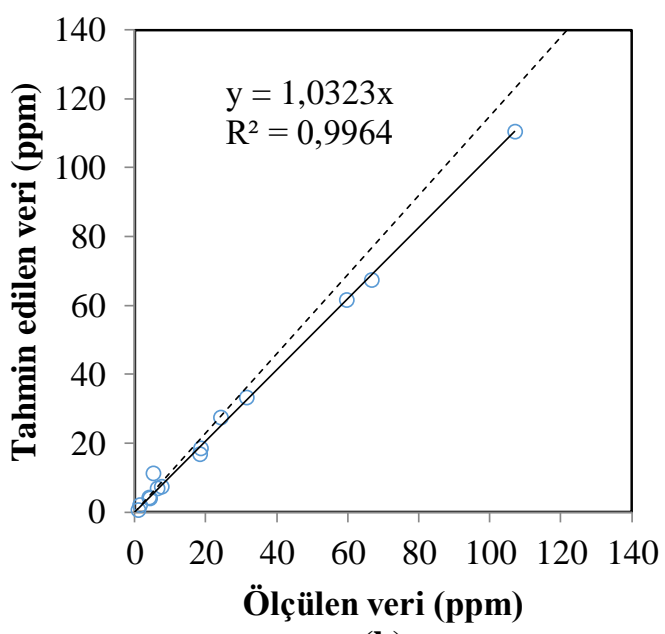

(b)

Şekil 7. Dört girdili ve 3-3-5-4 alt kümeli ANFIS modeline ait saçılım diyagramları (a) eğitim; (b) test 


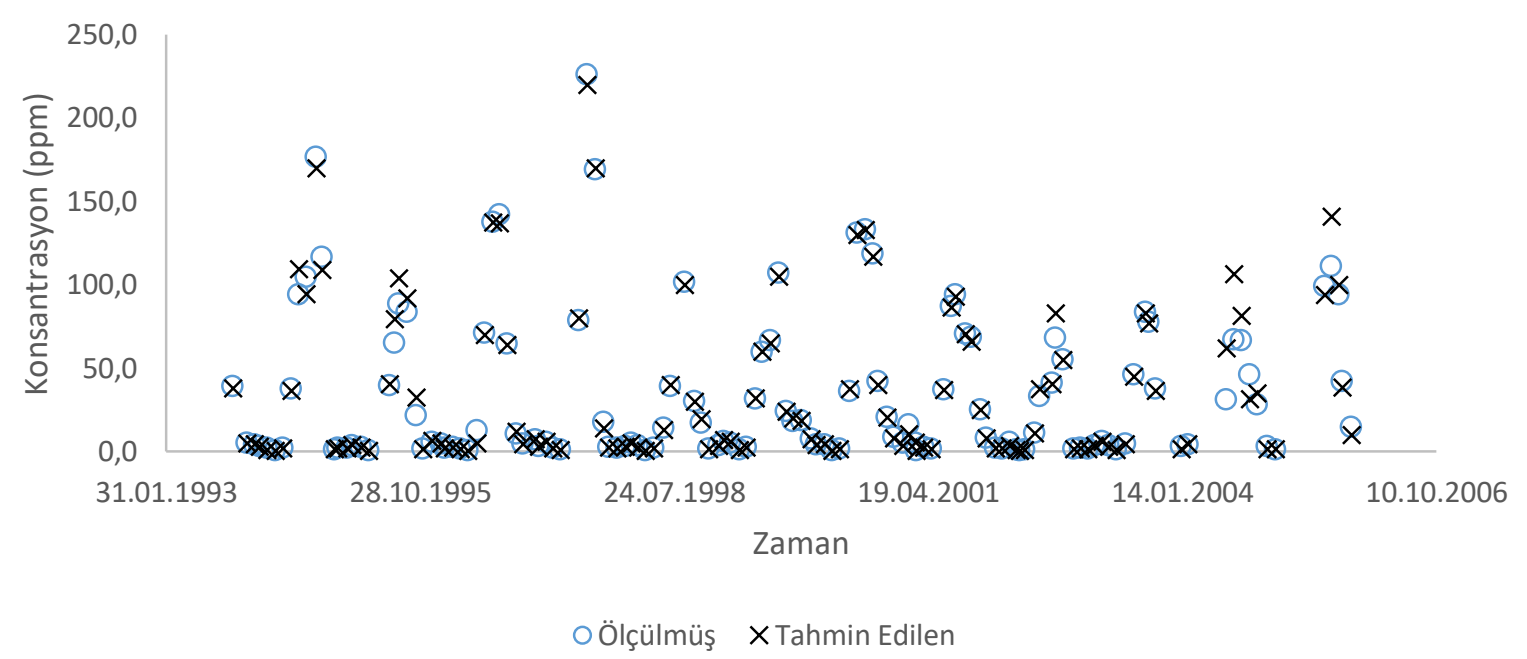

Şekil 8. Dört girdili ve 3-3-5-4 alt kümeli ANFIS modeline ait zaman serisi grafiği

\subsection{No'lu İstasyon için Tahmin Sonuçları}

Çalışmada öncelikle gözlem istasyonlarında yapılan ölçümler sonucu elde edilen veriler K-means algoritması kullanılarak kümelenmiştir. Farklı iki kümeleme işlemi yapılmıştır:

1. Veriler birbirleriyle kendi içerisinde kümelenmiştir.

2. Girdi verilerine karşılık gelen çıktı verilerinin konumları kümelenmiştir.

K-means algoritması ile kümelemeye ait sonuçlar Tablo 8'de sunulmuştur.

Tablo 8. K-means algoritması ile yapılan kümelemeye ait bilgiler

\begin{tabular}{|c|c|c|c|c|c|c|c|c|c|c|c|c|c|}
\hline & \multirow{2}{*}{$\begin{array}{l}\text { Küme } \\
\text { Sayısı }\end{array}$} & \multicolumn{2}{|c|}{ Küme 1} & \multicolumn{2}{|c|}{ Küme 2} & \multicolumn{2}{|c|}{ Küme 3} & \multicolumn{2}{|c|}{ Küme 4} & \multicolumn{2}{|c|}{ Küme 5} & \multicolumn{2}{|c|}{ Küme 6} \\
\hline & & $\begin{array}{l}\text { E. } \\
\text { S. }\end{array}$ & Ort. & $\begin{array}{l}\text { E. } \\
\text { S. }\end{array}$ & Ort. & $\begin{array}{l}\text { E. } \\
\text { S. }\end{array}$ & Ort. & $\begin{array}{l}\text { E. } \\
\text { S. }\end{array}$ & Ort. & $\begin{array}{l}\text { E. } \\
\text { S. }\end{array}$ & Ort. & $\begin{array}{l}\text { E. } \\
\text { S. }\end{array}$ & Ort \\
\hline \multirow{5}{*}{ ד্خ } & 2 & 66 & 0.56 & 5 & 16.42 & & & & & & & & \\
\hline & 3 & 61 & 0.13 & 6 & 6.53 & 4 & 18.05 & & & & & & \\
\hline & 4 & 61 & 0.13 & 6 & 6.53 & 3 & 16.1 & 1 & 23.9 & & & & \\
\hline & 5 & 61 & 0.13 & 3 & 4.67 & 3 & 8.4 & 3 & 16.1 & 1 & 23.9 & & \\
\hline & 6 & 54 & 0 & 7 & 1.14 & 3 & 4.67 & 3 & 8.4 & 3 & 16.1 & 1 & 23.9 \\
\hline \multirow{5}{*}{$\ddot{\ddot{\Xi}}$} & 2 & 59 & 37.71 & 12 & 225.1 & & & & & & & & \\
\hline & 3 & 54 & 31.22 & 14 & 159.4 & 3 & 336.2 & & & & & & \\
\hline & 4 & 48 & 25.11 & 12 & 96.49 & 8 & 194.4 & 3 & 336.2 & & & & \\
\hline & 5 & 48 & 25.11 & 11 & 92.70 & 7 & 175.2 & 3 & 247.4 & 2 & 366.7 & & \\
\hline & 6 & 48 & 25.11 & 11 & 92.70 & 7 & 175.2 & 3 & 247.4 & 1 & 339.8 & 1 & 393.6 \\
\hline \multirow{5}{*}{ 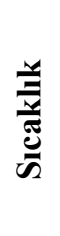 } & 2 & 38 & 7.26 & 33 & 19.33 & & & & & & & & \\
\hline & 3 & 23 & 5 & 26 & 12.53 & 22 & 21.5 & & & & & & \\
\hline & 4 & 14 & 3.43 & 22 & 9.18 & 19 & 15.84 & 16 & 22.69 & & & & \\
\hline & 5 & 12 & 3 & 18 & 8.11 & 10 & 12.20 & 15 & 16.47 & 16 & 22.69 & & \\
\hline & 6 & 12 & 3 & 14 & 7.57 & 10 & 10.8 & 13 & 14.69 & 10 & 19.20 & 12 & 23.42 \\
\hline
\end{tabular}

$\mathrm{Bu}$ tabloda; E. S. kısaltması eleman sayısını, Ort. kısaltması ise ortalama anlamların ifade etmektedir. Elde edilen sonuçlara bakıldığında; homojen dağılım gösteren elemanların yağış için beş küme, debi için dört küme ve sicaklık için dört küme olduğu görülmektedir. Tablo 9'un yöntem bölümünde bu kümeler işaretlenmiştir. Çalışmada K-means yöntemi ile oluşturulan ANFIS yöntemi modellerinin yanı sıra rastgele oluşturulan farklı alt kümelerle yapılan ANFIS modelleri de oluşturulmuştur. YSA ve ANFIS sediment modellerinin güvenilirliğinin kontrolünde daha hassas bir 
karşılaştırma yapabilmek için MLR modeli oluşturularak karşılaştırma yapılmıştır. Tablo 9'da küme sayısı belirlenen girdi değerleri ile oluşturulan ANFIS modelleri, YSA ve MLR modellerine ait sonuçlar verilmiştir. Tablo 9 incelendiğinde, K-means algoritması ile belirlenen en uygun alt küme sayıları ile oluşturulan ANFIS modelinden, hem rastgele oluşturulan ANFIS modellerine göre hem de YSA ve MLR modellerine göre daha iyi sonuçlar elde edildiği görülmüştür. Şekil 9'de en iyi sonuçların elde edildiği modele ait eğitim ve test aşamalarının $\mathrm{R}^{2}$ grafikleri verilmiştir. Ayrıca Denklem 11'de geliştirilen MLR modelinden elde edilen en iyi $\mathrm{R}^{2}$ değerinin denklemi verilmiştir. En başarılı model; test aşamasına ait en büyük $R^{2}$ ye göre belirlemiştir. Bu istasyonda en başarılı sonuç $\mathbf{R}^{2}=\mathbf{0 . 9 8 1 5}$ değeri ile alt küme sayısı K-means algoritması ile belirlenen ANFIS modelinden elde edilmiştir (Şekil 10).

$$
X_{2166}=X_{p} * 15.465+X_{p_{(-1)}} * 28.889+X_{Q} * 7.09+X_{T} * 3.039+(-128.159)
$$

Tablo 9. Oluşturulan YSA, ANFIS ve MLR modellerine ait $\mathrm{R}^{2}$ ve hata değerleri

\begin{tabular}{ccccccc}
\hline \multirow{2}{*}{ Yöntem } & \multicolumn{2}{c}{ Eğitim } & \multicolumn{3}{c}{ Test } \\
\cline { 2 - 7 } & $\mathrm{R}^{2}$ & MSE & MAPE & $\mathrm{R}^{2}$ & MSE & MAPE \\
\hline YSA - 1 Nöron & 0.8478 & 4.062 & 3.963 & 0.8041 & 3.123 & 2.963 \\
\hline YSA - 2 Nöron & 0.8482 & 5.829 & 5.652 & 0.7810 & 4.594 & 4.365 \\
\hline YSA - 3 Nöron & 0.8664 & 3.534 & 3.416 & 0.8116 & 4.683 & 4.426 \\
\hline YSA - 4 Nöron & 0.9411 & 3.832 & 3.628 & 0.8665 & 2.676 & 2.596 \\
\hline YSA - 5 Nöron & 0.8917 & 4.451 & 4.109 & 0.7524 & 4.528 & 4.169 \\
\hline YSA - 6 Nöron & 0.8371 & 5.585 & 5.369 & 0.7157 & 3.177 & 3.063 \\
\hline YSA - 7 Nöron & 0.8549 & 4.803 & 4.463 & 0.8203 & 3.538 & 3.267 \\
\hline YSA - 8 Nöron & 0.8345 & 5.077 & 4.960 & 0.7459 & 3.532 & 3.158 \\
\hline YSA - 9 Nöron & 0.9518 & 3.605 & 3.517 & 0.8062 & 2.671 & 2.415 \\
\hline YSA - 10 Nöron & 0.9333 & 2.701 & 2.623 & 0.8718 & 2.629 & 2.335 \\
\hline ANFIS - 3-3-3-3 Alt Küme & 0.9219 & 2.779 & 2.639 & 0.8226 & 3.495 & 3.109 \\
\hline ANFIS - 4-4-4-4 Alt Küme & 0.9527 & 2.661 & 2.461 & 0.7805 & 2.572 & 2.418 \\
\hline ANFIS - 5-5-4-4 Alt Küme & $\mathbf{0 . 9 9 4 4}$ & $\mathbf{2 . 0 1 5}$ & $\mathbf{1 . 8 7 6}$ & $\mathbf{0 . 9 8 1 5}$ & $\mathbf{1 . 8 7 5}$ & $\mathbf{1 . 8 6 3}$ \\
\hline ANFIS - 5-5-5-5 Alt Küme & 0.9452 & 2.081 & 1.963 & 0.8176 & 3.166 & 2.785 \\
\hline ANFIS - 6-6-6-6 Alt Küme & 0.9902 & 2.178 & 2.065 & 0.8455 & 1.963 & 1.815 \\
\hline ANFIS - 7-7-7-7 Alt Küme & 0.9935 & 2.169 & 1.996 & 0.8333 & 3.616 & 3.418 \\
\hline MLR & 0.8085 & 4.083 & 3.756 & 0.7061 & 4.749 & 4.364 \\
\hline
\end{tabular}

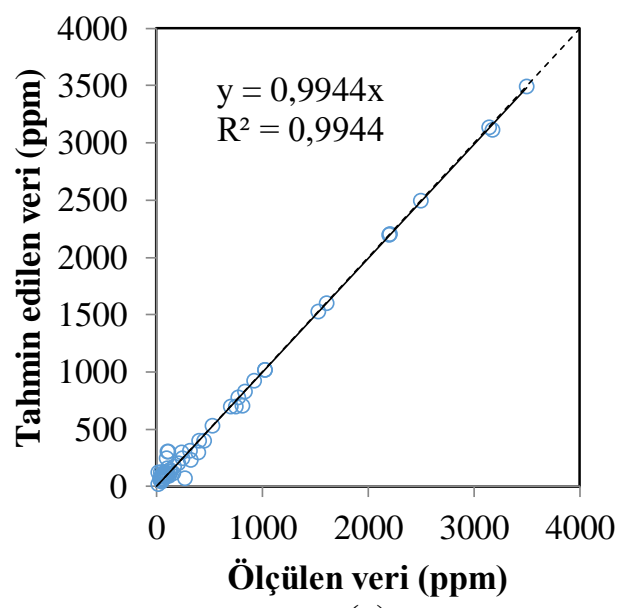

(a)

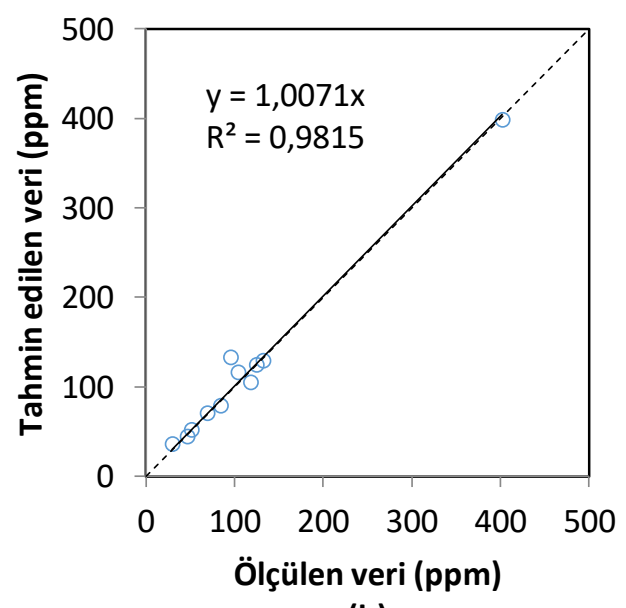

(b)

Şekil 9. Dört girdili ve 5-5-4-4 alt kümeli ANFIS modeline ait saçılım diyagramları (a) eğitim; (b) test 


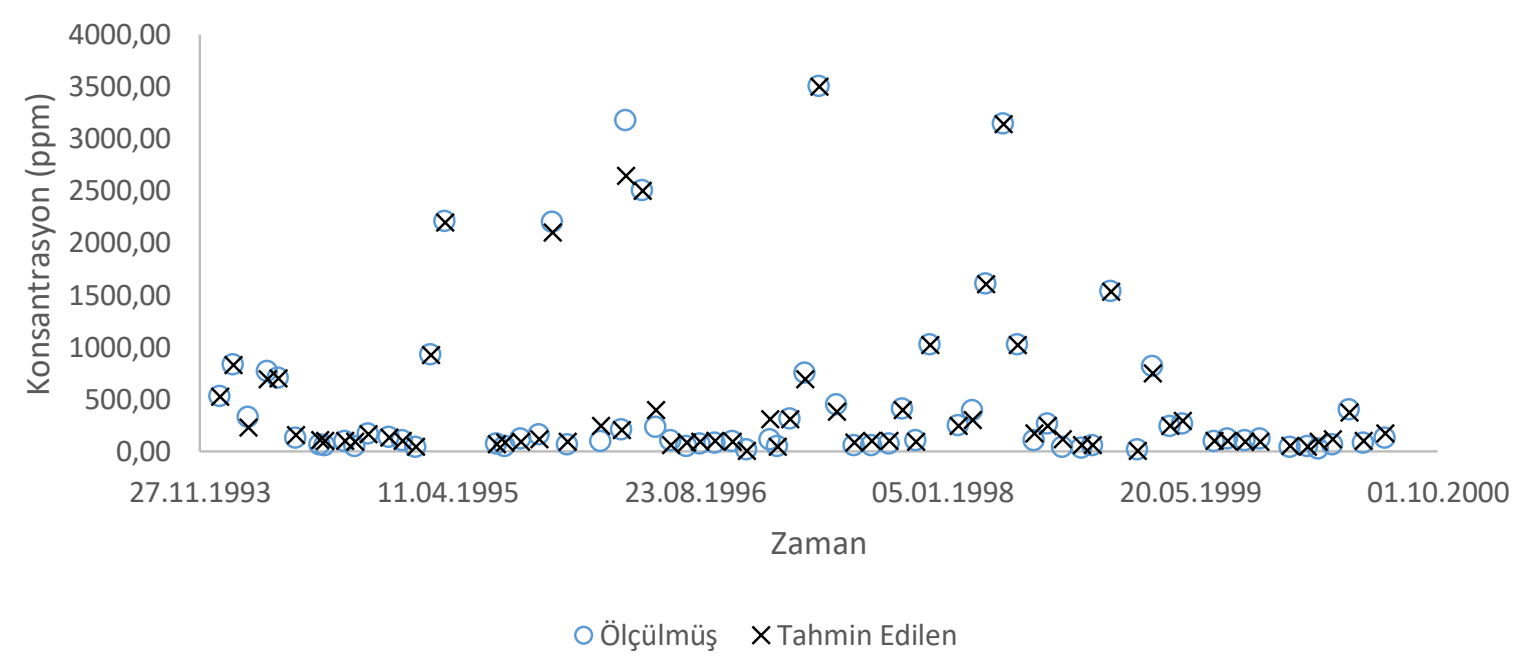

Şekil 10. Dört girdili ve 5-5-4-4 alt kümeli ANFIS modeline ait zaman serisi grafiği

\section{Sonuç ve Öneriler}

$\mathrm{Bu}$ çalışmada; YSA, ANFIS ve MLR yöntemlerinin sediment konsantrasyonunun tahmini için performansları araştırılmıştır. Bu amaçla 2102 No'lu Murat Nehri-Palu, 2164 No'lu Göynük Çay1Çayağzı ve 2166 No'lu Peri Suyu-Logmar AGI'leri için sediment tahmin modelleri geliştirilmiştir. Bu üç istasyonda Elektrik İşleri Etüt İdaresi (E.İ.E.) tarafından ölçülmüş olan sediment miktarı ile YSA, ANFIS ve MLR modellerinin tahminleri karşılaştırılmıştır. Yağışın gerçekleştiği günkü değeri (P), yağışın gerçekleştiği günün bir gün öncesindeki değeri $\left(\mathrm{P}_{-1}\right)$, debi ve sıcaklık değerleri girdi değişkeni, çıktı değişkeni olarak ise sediment konsantrasyonu kullanılmıştır.

ANFIS yöntemi modelleri oluşturulurken üyelik fonksiyonu sayısı hem rastgele hem de Kmeans algoritması ile kümeleme yapıldıktan sonra oluşturulmuştur. Kümeleme yapılırken veriler girdi değerlerine karşılık gelen çıktı değerlerinin konumlarının kümelenmesi şeklinde gerçekleştirilmiştir. Oluşturulan modeller ile elde edilen sonuçlar aşağıda verilmiştir.

1. Sediment tahmini için oluşturulan YSA ve ANFIS modellerinin MLR modeline göre ölçülen değerlere daha makul ölçüde yakınsadığı görülmüştür.

2. Üç istasyonda da regresyon katsayıları $\left(\mathrm{R}^{2}\right)$ açısından en başarılı sonuçlar K-means algoritması ile alt küme sayısı belirlenen ANFIS modelinden elde edilmiştir.

3. Ortalama yüzde hatası $(\mathrm{OYH})$ bakımından tüm istasyonlar için YSA ve ANFIS modellerinden birbirlerine yakın performanslar elde edilmiştir.

4. Üç istasyon arasından $\mathrm{R}^{2}$ ve $\mathrm{OYH}$ sonuçları incelendiğinde en başarılı sonuçlar 2164 No'lu istasyondan elde edilmiştir.

İlerleyen çalışmalarda; farklı girdi kombinasyonları kullanılarak sediment tahminine yönelik çalışmalar yapılabilir. Aynı zamanda K-means algoritması kullanılarak kümeleme yapıldığı takdirde modelleme sayısı minimuma düşürülebilir ve daha başarılı sonuçlar elde edilebilir.

\section{Yazarların Katkısı}

Çalışmada tüm yazarlar eşit oranda katkı sunmuştur.

\section{Çıkar Çatışması Beyanı}

Yazarlar arasında herhangi bir çıkar çatışması bulunmamaktadır.

\section{Etik Kurallar}

Yapılan çalışmada, araştırma ve yayın etiğine uyulmuştur. 


\section{Kaynaklar}

[1] Buyukyildiz M., Kumcu S. 2017. An estimation of the suspended sediment load using adaptive network based fuzzy inference system, support vector machine and artificial neural network models. Water resources management, 31 (4): 1343-1359.

[2] Khan M., Tian F., Hasan F., Chakrapani G. 2019. Artificial neural network simulation for prediction of suspended sediment concentration in the River Ramganga, Ganges Basin, India. International journal of sediment research, 34 (2): 95-107.

[3] Qasem S., Ebtehaj I., Riahi Madavar H. 2017. Optimizing ANFIS for sediment transport in open channels using different evolutionary algorithms. Journal of Applied Research in Water and Wastewater, 4 (1): 290-298.

[4] Riahi-Madvar H., Seifi A. 2018. Uncertainty analysis in bed load transport prediction of gravel bed rivers by ANN and ANFIS. Arabian Journal of Geosciences, 11 (21): 688.

[5] Malik A., Kumar A. 2015. Co-Active Neuro-Fuzzy Inference System (Canfis) And Multiple Linear Regression (Mlr) Based Suspended Sediment Modelling. Journal Of Indian Water Resources Society, 35 (2): 43-48.

[6] Nivesh S., Kumar P. 2017. Modelling river suspended sediment load using artificial neural network and multiple linear regression: Vamsadhara River Basin, India. IJCS, 5 (5): 337-344.

[7] Çeribaşı G., Doğan E. 2016. Aşağı Sakarya Nehrindeki Askı Maddesi Miktarının Esnek Yöntemler ile Tahmini. Karaelmas Fen ve Mühendislik Dergisi, 6 (2): 351-358.

[8] Kitsikoudis V., Sidiropoulos E., Hrissanthou V. 2015. Assessment of sediment transport approaches for sand-bed rivers by means of machine learning. Hydrological sciences journal, 60 (9): 1566-1586.

[9] Partovian A., Nourani V., Alami M. 2016. Hybrid denoising-jittering data processing approach to enhance sediment load prediction of muddy rivers. Journal of Mountain Science, 13 (12): 21352146.

[10] Firat M., Dikbaş F., Koc A., Güngör M. 2012. Classification of Annual Precipitations and Identification of Homogeneous Regions using K-Means Method. Teknik Dergi, 23 (115): 16091622.

[11] Kisi O., Zounemat-Kermani M. 2016. Suspended sediment modeling using neuro-fuzzy embedded fuzzy c-means clustering technique. Water resources management, 30 (11): 39793994.

[12] Şen, Z. 2004. Principles of Artificial Neural Networks. Turkish Water Foundation Publication, in Turkish.

[13] Avcar M., Saplioglu K. 2015. An artificial neural network application for estimation of natural frequencies of beams. International Journal of Advanced Computer Sciences and Applications, 6: $94-102$.

[14] Başkan Ö. 2004. İzole Sinyalize Kavşaklardaki Ortalama Taşıt Gecikmelerinin Yapay Sinir Ağları İle Modellenmesi. Yüksek Lisans Tezi, Pamukkale Üniversitesi, Fen Bilimleri Enstitüsü, Denizli, 120.

[15] Jang J. 1993. ANFIS: Adaptive-Network-Based Fuzzy Inference System. IEEE Transactions on Systems, Man, and Cybernetics.

[16] Seyedian S., Rouhani H. 2016. Assessing ANFIS accuracy in estimation of suspended sediments. Građevinar, 67 (12): 1165-1176.

[17] Mamdani E., Assilian S. 1975. An experiment in linguistic synthesis with a fuzzy logic controller. International Journal of Man-Machine Studies, 7 (1): 1-13.

[18] Tsukamoto Y. 1979. An approach to fuzzy reasoning method. In: M.M. Gupta, R.K. Ragade, and R. Yager, eds. Advances in fuzzy set theory and applications. Amsterdam: Elsevier Science Ltd., 137-149.

[19] Jang J.-S., Sun C.-T. 1993. Functional equivalence between radial basis function networks and fuzzy inference systems. IEEE Transactions on Neural Networks, 4 (1): 156-159.

[20] MacQueen J. 1967. Some methods for classification and analysis of multivariate observations. In Proceedings of the fifth Berkeley symposium on mathematical statistics and probability, 1 (14): 281-297. 
[21] Al Kindhi B., Sardjono T., Purnomo M., Verkerke G. 2019. Hybrid K-means, fuzzy C-means, and hierarchical clustering for DNA hepatitis $\mathrm{C}$ virus trend mutation analysis. Expert Systems with Applications, 121: 373-381.

[22] Vriend S., van Gaans P., Middelburg J., De Nijs A. 1988. The application of fuzzy c-means cluster analysis and non-linear mapping to geochemical datasets: examples from Portugal. Applied Geochemistry, 3 (2): 213-224.

[23] Burrough P., van Gaans P., MacMillan R. 2000. High-resolution landform classification using fuzzy k-means. Fuzzy sets and systems, 113 (1): 37-52.

[24] Lucieer V., Lucieer A. 2009. Fuzzy clustering for seafloor classification. Marine Geology, 264 (3-4): 230-241.

[25] Hartigan J., Wong M. 1979. Algorithm AS 136: A k-means clustering algorithm. Journal of the Royal Statistical Society. Series C (Applied Statistics), 28 (1): 100-108.

[26] Zeraatpisheh M., Ayoubi S., Brungard C., Finke P. 2019. Disaggregating and updating a legacy soil map using DSMART, fuzzy c-means and k-means clustering algorithms in Central Iran. Geoderma, 340: 249-258.

[27] Saplioglu K., Kucukerdem T. 2018. Estimation of Missing Streamflow Data Using Anfis Models and Determination of the Number of Datasets for Anfis: The Case of Yeşilırmak River. Applied Ecology And Environmental Research, 16 (3): 3583-3594.

[28] Sun W., Trover B. 2018. Multiple model combination methods for annual maximum water level prediction during river ice breakup. Hydrological Processes, 32 (3): 421-435.

[29] Hair J., Black W., Babin B., Anderson R. 2009. Multivariate Data Analysis. - Pearson. 